\title{
The Success of Picture Story Books in SD Science on Student Critical Thinking
}

\author{
$1^{\text {st }}$ Ermaniatu Nyihana \\ Yogyakarta State University \\ ermaniatu.nyihana2016@student.u \\ ny.ac.id
}

\author{
$2^{\text {nd }}$ Pratiwi Puji Astuti \\ Yogyakarta State University \\ pratiwi@uny.ac.id
}

$3^{\text {rd }}$ Zuhdan Kun Prasetyo

Yogyakarta State University

\begin{abstract}
This study aims to determine the effect of learning SD science by using picture story books on student learning outcomes in helping to grow their critical way of thinking. This research is Quasi Experimental research with Post Test Design Only Control Group Design. Data in this research is data of science learning result. Data were analyzed using descriptive analysis and inferential analysis using multivariate statistical analysis (Manova). The results of the research are as follows: 1) there are differences in learning outcomes of SD science in critical thinking of students who follow learning using picture story books with students using other publisher's books. 2) there are differences in learning outcomes of SD science in critical thinking between students who follow the learning by using picture story books with students using other publisher's books and 3) there is a difference of critical thinking between students who follow science lesson of SD by using picture story book with students who use other publisher's print books. Based on the results of this study, it can be concluded that learning SD science by using picture story books is more significant in the category of good, effective and successful than in other publisher print books in growing students' critical way of thinking.
\end{abstract}

Keywords - Picture Story Books, SD Science, Critical Thinking

\section{INTRODUCTION}

Along Critical thinking is the ability to think based on clear, logical and rational reasoning. The ability to think plays an important role in learning achievement, formal reasoning, success and creativity of students in learning because this stage of thinking is the core of student action regulator (Tindangen in Eka Ariyati journal, 2010: 1). The importance of thinking skills that students need so that there is an effort to hone their critical thinking skills.

1. One of Life Skill in 21st Century that need to be developed according to Depdiknas (2003) is critical thinking. In relation to this condition, the learning that must be developed is a learning that is able to nurture students to be able to think critically and not think mechanically. Critical thinking is a high-level thinking process and parallel to creative thinking (Elaine B. Johnson, 2009: 182). Through this critical thinking coaching, students are expected to be able to make decisions quickly and accurately based on the use of multiple points of view rather than based on only one particular point of view. So it takes careful preparation in forming students who have critical thinking that will be very useful for their lives in the future. According to Sladana (2016: 103) "In order to be prepared to succeed in life, education must focus on developing the critical thinking skills of the students. With these skills students will be ready to cooperate successfully, think critically and analytically, communicate efficiently and solve problems efficiently in the workplace. "

2. Scriven \& Paul (1992) defines critical thinking as an intellectual process that actively and conceptually conceptualizes, implements, analyzes, synthesizes and evaluates information gathered or produced from observation, experience, reflection, reasoning or communication, to guide beliefs and actions .

3. It can be concluded that the science-based illustrated story book with $\mathrm{PjBL}$ method of critical thinking is a book containing the story in it is reinforced by the picture and explained through the writings for further learning through the learning process involving the active students based on the syntax of learning to deliver students' from the ability to observe and recognize natural phenomena that occur carefully, carefully and maturely to then take appropriate steps in solving problems that occur due to the phenomenon through reasoning and logic students.

4. Critical thinking is the process of considering something that is studied in depth. As John Dewey (Alec Fisher, 2009: 2) has argued that critical thinking is essentially an active process in which one thinks deeply about things, asks oneself questions, finds information relevant to oneself rather than accepting things from people other. The creation of a scientifically based illustrated book-based picture book with the PjBL method is a real step in developing students' thinking skills to help understand the concept of science in contextual terms and to 
achieve deep understanding (Elaine B. Johnson, 2009: 185).

5. In addition the purpose of simple critical thinking is to ensure as far as possible that our thoughts are valid and true (Fahruddin Faiz, 2012: 2). In other words, critical thinking is an activity of thinking actively in understanding the correct concept and valid guaranteed.

\section{METHOD}

The The type of this research is quantitative research using quasi experiment which is aimed to compare two different treatment to the research subject, so that can be disclosed difference of influence between science-based picture book approach with PjBL method with book commonly used to the ability of critical thinking students.

The design of quasi experiments (quasi experiments) used is non-equivalent pretest posttest control group design. Nonequivalent control group design can use more than two groups, allowing each group to get treatment from only one group that is not treated (Gall, Gall \& Borg, 2007: 4-6). In the sense of the three groups, each is given treatment or treatment. The first experimental group used a science-based illustrated approach book with the PjBL method and the second experimental group used the Bupena book, while in the control group used the commonly used book. The research design can be seen in table 1 below.

TABLE 1. Quasi Experiment Design

\begin{tabular}{|l|l|l|l|}
\hline Groups & Pretest & Treatment & Posttest \\
\hline $\begin{array}{l}\text { Experimental } \\
\left(E_{1}\right)\end{array}$ & $T_{1} E$ & $X_{1}$ & $T_{2} E$ \\
\hline $\begin{array}{l}\text { Experimental } \\
\left(E_{2}\right)\end{array}$ & $T_{2} E$ & $X_{2}$ & $T_{4} E$ \\
\hline Control $(\mathrm{C})$ & $T_{5} C$ & $X_{3}$ & $T_{6} C$ \\
\hline
\end{tabular}
measurement instruments based on fulfillment of content validity criteria and construct validity. The fulfillment of the validity of the content of measuring instruments of critical thinking is done by using Core Competence (KI) and Basic Competence (KD) which contains themes of caring for animals and plants as a reference in the making of instruments. Based on the $\mathrm{KI}$ and $\mathrm{KD}$ are made indicators of achievement on the theme of caring for animals and plants are poured on the grating of critical thinking measurement test instruments. After that, based on the measurement instrument indicators the concept of understanding of the concept is made critical thinking test items. Fulfillment of construct validity using CFA in critical thinking measurement test instrument is done by first defining conceptual definition of critical thinking. Furthermore, based on the conceptual definition is defined operational definition of critical thinking. Then, based on the operational definition is made items of measurement instruments critical thinking tests. After fulfillment of logical validity, the instrument of critical thinking measurement test is done by facet validity test by requesting an expert review consisting of two expert lecturers. If it has been declared valid by the expert then the next stage, the validity of the instrument item of critical thinking measurement test is analyzed with the help of Quest program. Data validity of the items obtained by first testing the instrument to 26 grade 3 students who have received themes of caring for animals and plants. The reliability of the critical thinking measurement test instrument is assisted by using the Quest program.

\section{Descriptive Analysis}

Descriptive statistical analysis is used to give an overview of the implementation of research and present the measurement data obtained. The results of descriptive statistical analysis presented in the form of narration and table. Descriptive statistic calculation using SPPS 22.00 for windows and Mc. Excel.

\section{Inferential Analysis}

Inferential analysis was conducted to test the research hypothesis. Inferential statistics are done with the help of SPSS 22.00 for windows program. The provision used is if the significance value obtained after the test is greater than the 0.05 significance level, then the null hypothesis (Ho) is accepted and the alternative Hypothesis (Ha) is rejected. Conversely, if the significance value obtained after the test is smaller than the 0.05 significance level, then the null hypothesis (Ho) is rejected and the Alternative Hypothesis (Ha) is accepted.

Hypothesis Testing First: Differences in use of science-based picture book based approach with PjBL method of student's critical thinking. Testing the first hypothesis that the influence of the use of sciencebased picture book based approach $\mathrm{PjBL}$ method of critical thinking of students by doing Multivariate of Variance (MANOVA) test. The hypothesis proposed is as follows.

Ho: There is no difference in the use of science-based picture book based approach with $\mathrm{PjBL}$ method toward the critical thinking of second grade students on the theme of caring for animals and plants.

Ha: There is a difference in the use of science-based picture book based approach with PjBL method toward the critical thinking of second grade students on the theme of caring for animals and plants.

Decision-making is seen from Wilks's Lambda significance. The lower the statistical value it will have greater influence, Wilks's Lambda value ranges from 0-1 (Cornelius Trihendradi, 2013: 167).

Testing Second Hypothesis: The influence of the use of books cergam, Bupena and K'13 to critical thinking Learners. The second hypothesis test is the influence of using science-based picture book based approach with $\mathrm{PjBL}$, Bupena and K'13 methods to critical thinking by doing Paired-Samples T test. The hypothesis proposed is as follows. 
Ho: There is no influence of the use of scientifically based book based story books with PjBL, Bupena and K'13 methods for critical thinking of second grade students on the theme of caring for animals and plants.

Ha: There is influence of the use of science-based picture book based approach with PjBL, Bupena and K'13 methods toward class II critical thinking on the theme of caring for animals and plants.

Decision making is seen by comparison of Sig (2tailed) with $\alpha$, if the value of significance (2-tailed) $<\alpha \quad(0,025)$ then $\mathrm{Ho}$ is rejected (Cornelius Trihendradi, 2013: 119). This means that there is influence of the use of science-based picture book based approach with PjBL, Bupena and K'13 methods to critical thinking of second grade students on the theme of caring for animals and plants.

\section{RESULTS AND DISCUSSION}

The learning process begins with pretest and ends with posttest. Pretest is done to find out the results of critical thinking tests of learners before following the lesson with one of the books. Learning activities closed by holding posttest, which aims to determine the final ability of critical thinking of learners after following the lesson. Pretest and posttest critical thinking using test instruments. The following table 2 shows the results of pretest and posttest critical thinking statistics of learners.

TABLE 2. Descriptive Analysis Result Critical Thinking Learners

\begin{tabular}{|c|c|c|c|c|c|c|}
\hline \multirow{2}{*}{$\begin{array}{c}\text { Descriptive } \\
\text { Analysis } \\
\text { Result }\end{array}$} & \multicolumn{3}{|c|}{ Classroom Experiment } & \multicolumn{2}{c|}{$\begin{array}{c}\text { Classroom } \\
\text { Control }\end{array}$} \\
\cline { 2 - 7 } & \multicolumn{2}{|c|}{ Cergam } & \multicolumn{2}{c|}{ Bupena } & \multicolumn{2}{|c|}{ K'13 } \\
\cline { 2 - 7 } & Pre & Post & Pre & Post & Pre & Post \\
\hline Mean & 14.18 & 20.81 & 14.14 & 18.42 & $\begin{array}{c}14 . \\
17\end{array}$ & $\begin{array}{c}16.8 \\
2\end{array}$ \\
\hline $\begin{array}{c}\text { Standard } \\
\text { Deviation }\end{array}$ & 1.86 & 2.84 & 2.41 & 2.88 & $\begin{array}{c}2.5 \\
7\end{array}$ & 4.59 \\
\hline
\end{tabular}

The result of descriptive analysis of critical thinking ability of learners showed that the students using picture book have average critical thinking of 14,18 before studying and experienced an average increase to 20,81 after following lesson with book of cergam. Learners using the Bupena book have an average critical thinking of 14.14 and an increase to 18.42 after learning. There was also an increase in the average score of critical thinking of learners using K13 book indicated by an average initial score of 14.17 and a mean score after following the learning of 16.82. Based on the data presented in the table, it can be concluded that learners who follow the learning by using the book cergam, Bupena and K'13 experienced an increase in average critical thinking after following the learning by using the books.

1) Hypothesis Testing First: The use of sciencebased picture book based approach with PjBL method of critical thinking
Testing the first hypothesis that the influence of the use of science-based picture book based approach PjBL method of critical thinking learners by doing Multivariate of Variance (MANOVA) test. A multivariate test is performed for the postes of critical thinking skills at the end of the meeting. The multivariate test used is Wilks's Lambda statistic. The lower the statistical value it will have greater influence, Wilks's Lambda value ranges from $0-1$. Table 3 below presents the results of multivariate statistics with the Wilks's Lambda test.

TABLE 3. Descriptive Analysis Result Critical Thinking Learners

\begin{tabular}{|c|c|c|c|c|c|c|}
\hline \multirow{2}{*}{$\begin{array}{c}\text { Descriptive } \\
\text { Analysis } \\
\text { Result }\end{array}$} & \multicolumn{3}{|c|}{ Classroom Experiment } & \multicolumn{2}{c|}{$\begin{array}{c}\text { Classroom } \\
\text { Control }\end{array}$} \\
\cline { 2 - 7 } & \multicolumn{2}{|c|}{ Cergam } & \multicolumn{2}{c|}{ Bupena } & \multicolumn{2}{c|}{ K'13 } \\
\cline { 2 - 7 } & Pre & Post & Pre & Post & Pre & Post \\
\hline Mean & 14.18 & 20.81 & 14.14 & 18.42 & $\begin{array}{c}14 . \\
17\end{array}$ & $\begin{array}{c}16.8 \\
2\end{array}$ \\
\hline $\begin{array}{c}\text { Standard } \\
\text { Deviation } \backslash\end{array}$ & 1.86 & 2.84 & 2.41 & 2.88 & $\begin{array}{c}2.5 \\
7\end{array}$ & 4.59 \\
\hline
\end{tabular}

The result of multivariate analysis using Wilks's Lambda test showed value equal to 0,213 , and F_count equal to 46,656 . The value of significance shows a 0.000 number smaller than $0-1$ so Ho is rejected. Based on the results of the analysis it can be concluded that there are differences in the use of illustrated books based on scientific approach with PjBL method of critical thinking. After the multivariate test on posttest result of critical thinking ability, univariate test.

Univariate test is done on posttest value of critical thinking ability of learners that function to analyze each variable. The following is a univariate test result on the posttest value of critical thinking and communicating ability of learners presented in table 4 below.

TABLE 4. Univariate Test Result

\begin{tabular}{|c|l|c|c|}
\hline \multicolumn{4}{|c|}{ Test of Between-Subject Effects } \\
\hline Source & Dependent Variable & F & Sig. \\
\hline $\begin{array}{l}\text { Story book } \\
\text { with picture }\end{array}$ & Critical Thinking & 8,859 & 0,000 \\
\hline
\end{tabular}

Pursuant to result of univariate test analysis at posttest value show that for dependent variable in the form of critical thinking show F_Count equal to 8,859 and significance value less than 0,05 (Sig. $=$ $0,000)$. The value indicates that the three instructional books have an influence on the critical thinking ability of learners positively and significantly. These values indicate that the three instructional books have an influence on critical thinking ability positively and significantly.

After univariate test to know the influence of learning book simultaneously to the ability of critical thinking, then Tukey test to determine the influence of each learning book on the critical thinking ability of learners after following the theme 6 learning, care for animals and plants. Tests were performed on each of the mean students' critical thinking posttest using the Tukey test. The use of the Tukey test aims to 
compare all pairs of treatment averages after a multivariate test. Tukey test results for posttest critical thinking value are presented in table 5 below.

\begin{tabular}{|c|c|c|c|c|c|}
\hline \multicolumn{6}{|c|}{ TABLE 5. Tukey Test Result } \\
\hline $\begin{array}{c}\text { Dependent } \\
\text { Variable }\end{array}$ & (I) Class & (J) Class & \begin{tabular}{|l} 
Mean \\
Difference \\
(I-J)
\end{tabular} & $\begin{array}{l}\text { Std. } \\
\text { Error }\end{array}$ & Sig. \\
\hline \multirow[t]{6}{*}{ Critical } & \multirow[t]{2}{*}{ Cergam } & Bupena & $2.3862^{*}$ & .95952 & .015 \\
\hline & & $\mathrm{K}^{\prime} 13$ & $3.9872^{*}$ & .95137 & .000 \\
\hline & \multirow[t]{2}{*}{ Bupena } & Cergam & $-2.3862^{*}$ & .95952 & .015 \\
\hline & & $\mathrm{K}^{\prime} 13$ & 1.6010 & .94253 & .093 \\
\hline & \multirow[t]{2}{*}{ K'13 } & Cergam & $-3.9872^{*}$ & .95137 & .000 \\
\hline & & Bupena & -1.6010 & .94253 & .093 \\
\hline
\end{tabular}

Based on the Tukey test results showed that the significance value of Cergam and Bupena books is smaller than $0.05(\mathrm{Sig}=0.015)$ which means that there is a difference in average thinking of both books. The results of the analysis for Cergam's book and K'13 book indicate a significance value less than 0.05 (Sig. $=0,000)$ which means that there is a difference in the average critical thinking of both textbooks. In the test results of the books Bupena and K'13 showed a significance value above 0.05 ( $\mathrm{Sig}=$ 0.093) which means that there is no difference in average thinking on both books.

Based on the result of Tukey test analysis for the learning book on communicating, it is also known that the smaller significant value is 0.05 ( $\mathrm{Sig}$. = 0,000 ) for the three instructional books. The significance value means that there is difference of average communicating ability in the three instructional books.

Hypothesis Testing Influence Book Cergam, Bupena and K'13 to Critical Thinking Learners. Data analysis is done by comparing mean of each dependent variable that is measured, that is critical thinking of learners. The comparison of mean data before and after treatment aims to test the mean equality between experimental classes ie Cergam and Bupena Books, and control class by using $\mathrm{K}^{\prime} 13$ book on the ability of critical thinking learners simultaneously. The mean comparison is also performed both on the pretest and posttest ability of critical thinking and communicating learners. This comparison aims to test the hypothesis of the influence of each textbook on each dependent variable, namely the ability of critical thinking. The mean comparison aims to find out the comparison between the influence of the book with Bupena, the comparison between cergam and $\mathrm{K}^{\prime} 13$, and the comparison between Bupena's book with K'13 to the critical thinking ability of learners on theme 6 learning, caring for animals and plants.

To know the influence of learning book, book of cergam, Bupena and $\mathrm{K}^{\prime} 13$ to the critical thinking ability of learners, $t$ test is paired-sample t-test. This test is done to know the difference of the average ability of critical thinking of learners before and after follow the theme 6 learning by using book cergam. The following test results paired sample $t$ test presented in table 6 below.

\begin{tabular}{|c|c|c|}
\multicolumn{3}{|c|}{ TABLE 6 Paired T Test Result } \\
\hline Variabel & Story Book with Picture & Sig. \\
\hline \multirow{3}{*}{ Critical Thinking } & Cergam & 0,000 \\
\cline { 2 - 3 } & Bupena & 0,000 \\
\cline { 2 - 3 } & K'13 & 0,000 \\
\hline
\end{tabular}

Based on the results of paired sample $t$ test analysis showed that the overall average of pretest and postes, for critical thinking in the book of cergam, Bupena and K'13 showed significant differences, indicated by a significance value of 0.000 ( Sig $==0.05)$. It means that the average value of pretest with postes is different, so there is the influence of the book on the ability of Cenggam critical thinking and Bupena book to the ability of critical thinking. It can be concluded that from the three textbooks, picture books have more influence than the other two

\section{ACKNOWLEDGEMENTS}

Thanks to Dr. Pratiwi Puji Astuti, M.Pd. and Prof. Zuhdan Kun Prasetyo, MA. which has been providing direction and guidance.

\section{REFERENCES}

[1] Depdiknas. (2003). Kurikulum 2004 standar kompetensi sekolah dasar. Jakarta: Depdiknas.

[2] Scriven \& Paul. (1992). Critical thinking: basic question \& answer. Critical Thinking Community. [Online]. Tersedia: http://www.criticalthinking.org/pages/criticalthinking-basic-questions-ampanswers/409\%20.html 30 Oktober 2017

[3] Cornelius Trihendradi, (2007), Langkah mudah menguasai analisis statistik menggunakan SPSS 15, Penerbit Andi, Yogyakarta.

[4] Alec Fisher. (2009). Berpikir Kritis Sebuah Pengantar. Jakarta: Erlangga

[5] Eka Ariyanti. (2010). Pembelajaran Praktikum untuk Meningkatkan Kemampuan Berpikir Kritis Siswa. Jurnal Matematika dan IPA. Vol. I No. 2 pp. 1

[6] Johnson, Elaine B. (2009). Contextual Teaching and Learning. (Edisi Terjemahan Ibnu Setiawan). Bandung: MLC

[7] Fahrudin Faiz, (2012). Thinking Skills Pengantar Menuju Berpikir Kritis. Yogyakarta: Suka Press.

[8] Borg, W. R. \& Gall, M.D. (2003). Educational Research: an introduction (7th ed.). New York: Longman

[9] Sladana Zivkovic, (2016). A Model of Critical Thinking as an Important Attribute for Success in the 21 st Cwntury. No.232 pp. 102-108 